\title{
State, Economy and Democracy in Brazil and Latin America
}

Historians from throughout the world affirm that significant changes have occurred in the directions of humanity since the time when men questioned the theocentric explanations that illuminated human knowledge for a long time, thus marking the passage from Medieval times to Modernity. This passage influenced various fields of knowledge such as the French encyclopedists; astronomy and physics, with Pascal and Newton; chemistry with Lavoisier; mathematics with Descartes; medicine and biology from Hippocrates to Darwin. Transformations also occurred in the arts, culture, literature, and in engineering and all fields of knowledge that could be submitted to human rationality with humans at the center of concern. It is evident that this changed traditional forms of exercising power and the forms of organization of different societies. The state, economy and democracy came to have their forms and contents resignified at the heart of the process of constitution of social classes, liberal economies and bourgeois democracies.

If in the old continent this process is situated in time at the transition from the feudal regimes to the bourgeois societies, in Latin America a similar process not only took place at a much different historic time, but was also marked by the violent colonialist and imperialist expropriation of our original peoples, by the dependent and subordinated constitution of our economies - characterized by degrading and exponential super-exploitation of the labor force - and by the feeble formation of democratic regimes that interchanged, over history, with authoritarian civil-business and or military regimes.

These particularities, as well as the general directions and universal characteristics of state, democracy and different economic forms - although they are central elements of the class struggle around the world - for much time were not issues that had prestige in academic and intellectual spaces. The deficit among us in relation to studies and research in these areas has only been recently faced with the advent of theories that revive our particularity of being a subcontinent that has been expropriated and with dependent economies, as shown by the Marxist theory of dependency, associated to recent experiences of democratic alternatives that offer new forms of conducting politics, different from the traditional, imperialist, neoliberal orientations, such as the experiences in Venezuela, Bolivia, Uruguay and even Brazil. These two sets of factors have allowed us to give greater attention not only to the broad issues cited, but to others that stem from them, such as the configuration of public policies, the forms of administration and scope of state apparatus, the transformations of institutions and the regulationism that stems from them, among other issues.

It is in the wake of this revival that Revista Katálysis presents us with an edition dedicated entirely to issues of the state, economy and democracy in Latin America. The reflections contained here provide us the opportunity to problematize from both a theoretical and practical perspective the constitutive dimensions of our societies that have the state as its main agent of diffusion.

As an internal and external element of dispute, the bourgeois states materially condense the contradictions that arise from the correlation of forces found in societies, and for this reason, as much as they may tend to meet social and human needs (and this is directly related to the quality of democratic statues) their coercive nature is unavoidable. Or, as Jaime Osório affirms (2014, p. 17)

\section{(@) $\mathbb{Q} \otimes$}

(c) The Author(s). 2018 Open Access This article is distributed under the terms of the Creative Commons Attribution-NonCommercial 4.0 International License (http://creativecommons.org/ licenses/by-nc/4.0/), which permits use, distribution, and reproduction in any medium, since it's for non-commercial purposes, and provided you give appropriate credit to the original author(s) and the source, provide a link to the Creative Commons license, and indicate if changes were made. 
The state is much more than the domination of classes. But it is essentially domination of classes. The state is much more than the condensation of power relations, but it is fundamentally the main condensation of power relations. The state is much more than the relations that shape a community, but it is essentially a community, although an illusory one. Finally, the state is much more than coercion, but it is mainly concentrated violence.

It is thus essential to consider the state in relation to history and class struggle, because it is the decisive element for both the reiteration of capitalist/bourgeois domination and for the socialist-revolutionary transition.

In the same manner, it is necessary to revive the original project of bourgeois democracy so that we can, by accompanying its evolution, submit it to criticism and confront it with the historic possibilities to substitute it for socialist democracy, or in the words of Marx, for the dictatorship of the proletariat.

Bourgeois democracy, for some time, was largely responsible for the civilizatory contents that capitalism would present until its monopolist phase. It is bourgeois democracy that inaugurated the concept of human rights, for example, which raised t counter absolute monarchies reveals its undeniable civilizatory dimension. As the political form of liberal states, bourgeois democracy did not take long to present its structural contradictions, and the central notion that the bourgeois democratic regimes are neutral forms of administration of social life, in relation to the class conflict. Therefore, we find ourselves before a democratic dictatorship of the bourgeoisie sustained under the discourse of formal equality.

The democratic transition in Latin America, under the mantle of the cited formal equality, maintained, from an economic perspective, the structural dependence to the degree to which the region continued to have low levels of industrialization and technological dependence. The export model based on agricultural and mining commodities, now qualified as a secondary export model, has intensified the economic exclusion of the masses of workers at the same time as which it re-establishes the local elites. Curiously some Latin American governments encouraged domestic consumption through state inducements, at the same time as they permitted advances in liberalization and deterritorialization of capital. For some time, this logic, which was only possible based on conservative articulations between factions of the dominant class and factions of the working class, presented immediate results that created the illusion of development. Nevertheless, in the following moment, they became unsustainable, because the longevity of the strategy would depend fundamentally on the realization of reforms of the structural base such as agrarian, tax and political reform, as well as other measures, a movement that was not in the interest of the old and new elites. In this way, dependence was reaffirmed and our continent continued to contradictorily have the highest rates of urbanization and of inequality.

As if this was not enough, the depletion of the fragile adjustments between labor and capital opened significant historic gaps in the relation between the classes and allowed a destructive movement of ultraconservative restoration to beat us down (Brazil, Honduras, Paraguay and Argentina are significant examples). Whether by political/institutional coups d'état or even through the illusion of suffrage, Latin America is at a complex historic crossroads. The articles of this edition are thus a small but significant effort to help us understand these dilemmas and inspire us to seek solutions that apply to the daily struggle and revolutionary practice.

Renato Francisco dos Santos Paula, November 2017.

\section{Reference}

OSORIO, J. O Estado no centro da mundialização: a sociedade civil e o tema do poder. São Paulo: Outras Expressões, 2014.

\section{Renato Francisco dos Santos Paula}

renato.paula@gmail.com

Doctor in Social Work from the Pontific Catholic University of São Paulo (PUC-SP)

Professor in the school of Social Work and Director of the Regional Unit of the Federal University at Goiás (UFG)

\section{UFG - Goiás Regional Management}

Av. Bom Pastor, s/n - Areião

Goiás - Goiás - Brasil

CEP: 76.600-000 